\title{
Reflections on the Needs and Expectations of Integral Sexuality Education in Adolescents
}

\author{
Damarys Chacón 0'farrill ${ }^{1}$ and Alba Cortes Alfaro ${ }^{2 *}$ \\ ${ }^{1}$ Specialist of I Grado in Ginecobstetricia, Specialist of II Degree in Integral General Medicine, Master in Integral Care to \\ Women, Assistant Professor, Mayabeque, Cuba
}

${ }^{2}$ Specialist of I and II Degree in School Hygiene, Master in Epidemiology, Professor and Assistant Researcher, Assistant, National Institute of Hygiene, Epidemiology and Microbiology, Cuba

*Corresponding author: Alba Cortes Alfaro, Specialist of I and II Degree in School Hygiene, Master in Epidemiology, Professor and Assistant Researcher, Assistant, National Institute of Hygiene, Epidemiology and Microbiology, Cuba

ARTICLE INFO

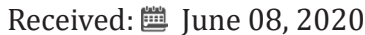

Published: 㓞 June 16, 2020

Citation: Damarys Chacón O'farrill, Alba Cortes Alfaro. Reflections on the Needs and Expectations of Integral Sexuality Education in Adolescents. Biomed J Sci \& Tech Res 28(2)-2020. BJSTR. MS.ID.004632.

Keywords: Adolescence; Comprehensive Sexuality Education

Abbreviations: SDGs: Sustainable Development Goals; WHO: World Health Organization; STIs: Sexual Transmission Infections; AIDS: Acquired Immunodeficiency Syndrome

\section{ABSTRACI}

Introduction: Adolescence (a) is a well-defined stage of the human life cycle between childhood and adulthood, between 10 and 19 years of age. They are considered as a vulnerable group when presenting risky social and/or sexual behaviors that expose them to sexual and reproductive health problems such as unwanted pregnancies and sexually transmitted infections(STIs), affecting health indicators.

Object: Reflexionar on the needs and expectations of Integral Sexuality Education in adolescents.

Methods: A bibliographic review was carried out where the databases included in the services LILACS, EBSCO and HINARI were consulted, and very good coverage was reached, both in Cuba, in Latin America and the Caribbean, and in the rest of the world.

Conclusion: it is shown that comprehensive sexuality education is increasingly necessary in a society that is wellin formed, and yet has high doses of ignorance and errors in these issues. The school is attached great importance to the powerful influence it presents not only on students but also on the family and community. Preventive interventions with high educational quality that lead to early prevention of these risky behaviors are encouraged.

\section{Introduction}

The Sustainable Development Goals (SDGs) of the 2030 agenda emphasize 3, 4 and 5 the protection of human rights and gender equality promotion and the empowerment of women and girls, with the preservation of sexual and reproductive health of vital importance. A quality, inclusive and equal education is required for this [1]. The Public Education and Health Msública in support of guidelines led by the World Health Organization (WHO) and the United Nations Children's Fund (UNICEF) have set the goal of comprehensive training for new generations by creating methodological guidelines for this purpose [2-4]. Programs have been carried out in Cuba such as the Resolución Ministerial 139/2011 by the Ministry of Education with curriculum involvement to strengthen issues for the prevention of sexual transmission infections (STIs), early landing, self-care, taking into account sexual rights, gender equality with this is to form adequate basic values for responsible social and social behaviour. With curricular involvement to strengthen topics for the prevention of infections of $\mathrm{t}[5]$.

The authors como Araujo Gonza lez agree on the concept of ávulnerability so that adolescents are a vulnerable group when they are in risky situations and do not present skills and tools for the proper solution of $s$ them. Health indicators for teenage pregnancies, the incidence of curable and un curable STIs, sexual abuse are highlighted the increase in the world at these ages [6-9]. The sarrollo of skills through knowledge must be characterized by the assertive dialogue of the adolescents, so it is suggested to reize educational interventions whose methodology isé imbued with the main role of these, of the inclusive, inclusive and participatory 
character. Here is the ephecctividad of the integral education of the ualuality (EIS) so that the future generation enjoys a full and responsible sexuality $[10,11]$. Marquez F. in its study, he emphasizes prevention and the primary role of the school and with rope with the Report of Secing the Education Mundial in calling for action in favor of education as a central element of the SDGs emphasizing that it is inclusive and of quality $[12,13]$.

\section{Methods}

In order to carry out this review and to provide readers with an update on the subject in question, the databases included in the LILACS, EBSCO and HINARI services were consulted and very good coverage was achieved, both in Cuba, Latin America and the Caribbean, and in the rest of the world. Websites were also visited on the Internet for a must-consult for their prestige and leadership on the subject. The terms were used: adolescence, vulnerability and risk in the adolescent stage, need for comprehensive sexuality education, educational measures among others. To inform this research work, a theoretical review has been carried out, collecting different aspects related to the importance of sexuality education at this stage of life. The controlled language DeCS was consulted for the development of search strategies and the corresponding Boolean operators were included.

\section{Development}

Adolescence is a well-defined stage of the human life cycle between childhood and adulthood characterized by profound biological, psychological and social changes. It is the end of the World Health Organization as the period of life that passes between them 10 to 19 years of age [14]. This is a time of continuous biopsychosocial changes. Biologicals are associated with the period of puberty that marks the beginning of adolescence. These changes occur in four directions: anthropometric (relative to weight and height), physiological (neurovegetative alterations) endocrine (increased accelerated hormone production) and sexual maturation that includes two groups of transformations: primary sexual characteristics, structural changes of the organs of the reproductive system; and secondary sexual characteristics, traits of sexual maturity, not directly related to the structure of sexual organs [15]. Changes at the brain level are of great importance as they would explain risky behaviors and social behaviors specific to adolescence $[14,15]$.

During this stage several brain transformations occur as they are: the neural pruning that occurs first in the posterior area of the brain and culminates in the frontal cortex (which controls reasoning, decision-making and emotional control); the pineal gland that releases the hormone Mecatona produces it late in the day so teens are enthusiastic at night and find it hard to get up for the day; actions at these ages are more guided by the amygdala so emotional and instinctive reactions, fear and aggressive behavior are common [16]. Adolescents respond badly to types of thinking that require looking to the future to visualize the outcome of their actions, a feature that assesses the ability to take risks and arises between the ages of 15 and 18 [17]. Risky behaviors can be sexual or social. The combination of both is common and very dangerous for sexual and reproductive health so adolescence is considered a vulnerable group [18]. The main consequence of risky sexual behavior is part of reproductive harm with presence in the increase in early pregnancies, abortions and STIs and that in turn if it relates to risky social behaviors can unfortunately culminate with the frustration of the life project $[18,19]$.

Negative increase in health status indicators confirm this. There are global trends that make this population characteristic as is the fact that the age of onset of sex is earlier, placing around 15 years. In 2015, adolescent fertility accounted for $15.2 \%$. Latin America and the Caribbean is the only region where the births of girls under the age of 15 increased. Predominantly rural areas with adolescent fertility that accounts for $21 \%$ of total fertility. Every year there are 44 births in the world per 1000 girls aged 15 to 19 [20]. The World Health Organization (WHO) has estimated that STIs including acquired immunodeficiency virus/Acquired Immunodeficiency Syndrome (HIV/AIDS) are, on a global scale, the most important cause of disease among men aged 15 to 49 and the second (after maternal causes) among young women in developing countries $[9,20]$. The adolescent population in Cuba represents $11.92 \%$ [21]. Cuba's 2018 statistical yearbook shows that the incidence of Syphilis decreased compared to 2017 (from 5088 to 4706 respectively). Like the incidence of AIDS: with a tendency to decline as it was reported: 258 cases and for 2018: 161. However, as far as Blenorragia is A case, there was an increase, with 2,904 cases reported in 2017 and by 2018: 2953 [22].

This calls for greater actions aimed at protecting adolescent girls in terms of sexuality, being a universal right of all people in relation to full, healthy enjoyment and free from all discrimination and social injustice $[23,24]$. The authors agree with other authors that teenagers may have assertiveness, who can discern between right and wrong, and who may be responsible for their actions, that they must demand and live their rights [25]. For adults who accompany them at this stage of life, teachers and family members, knowing certain characteristics of adolescence can help understand them, anticipate and manage behaviors, and at the government level establish policies and design favoring strategies for this social group [26,27]. The World Health Organization (WHO) has set targets for 2030, including: ending AIDS epidemics, ensuring universal access to sexual and reproductive health services, including family planning, information and education, and integrating reproductive health into national strategies and programmes [1,2,24]. We are obliged to think of adolescence to prevent respa financially. The formula is where Integral Sexuality Education (EIS) is needed, thus favoring responsible sexuality [28,29].

The EIS is a teaching/learning process that relies on competent studies on the cognitive, psychological, physical and social aspects 
of sexuality, sees sexuality holistically and as part of emotional and social development gives the opportunity to acquire life-essential skills as well as develop positive attitudes and values [17]. Their goal is to provide knowledge based on empirical data, skills, attitudes and values that will empower them to enjoy health, wellbeing and dignity; establish social and sexual relationships based on respect; analyze how your decisions affect your own well-being and that of others; understand how to protect and care for their rights throughout their lives [30,31]. A quality EIS, properly taught and based on gender equity and sexual rights will provide adolescents with tools for the prevention of sexually transmitted infections, early pregnancies, self-care, will work on the formation of basic values whether moral, work as well as those related to lifestyles $[31,32]$. Intersectorality and interdisciplinarity are essential to achieve better results and effectively address problems related to sexuality in adolescents. We talk about the integration of programs designed in adolescents and young people either by pedagogical institutes and school health services without forgetting to add disciplines such as sociology, psychology, philosophy and legal sciences [25-27].

It plays great importance then the school as a socializing agent, where teenagers spend much of their days. It is there that teachers interact directly with them and impart them comprehensive knowledge of sexuality either through the curriculum as a direct part of their lives [33]. The Cuban curriculum educational conception assumes the process in sexuality education with a gender and sexual rights approach from a comprehensive crosssectional perspective that promotes an educational process on an active basis [5,34]. To achieve cognitive incorporation of sexuality, the acquisition of correct attitudes and beliefs with high perception of risk should be developed educational intervention strategies relevant to this age [34]. In order to carry out educational interventions, advanced scientific methodologies of a qualitative type must be taken into account with the triangulation of these, the information and communication techniques must be incorporated in the era of digitization so ingrained in adolescents and that will get them all their attention and therefore flattering the incorporation of knowledge on the subject [15,31-33]. It is apparently an arduous task to education sexuality in adolescents in favor of sexual and reproductive, but it will be achieved and positive impact if you have a holistic approach $[35,36]$.

\section{Conclusion}

During the stage of adolescence in which biological changes of puberty occur, with the presence of psychological and social transformations the sphere of sexuality enters as a remarkable element. Educational actions on through comprehensive education of exuality in adolescence will allow them to make informed decisions about their sexuality and health, prepare for life and adopt responsible social and sexual behaviors, thereby not only preserving sexual and reproductive health but overall health quality of life. The work of the actors responsible for training adolescents, such as escuela, should aim for preventive educational interventions taking into account community, equality and economic rights.

\section{References}

1. Draft final document of the United Nations summit for the adoption of the post-2015 development agenda. PAHO/WHO.

2. WHO (2018) WHO Recommendations on Adolescent Health and Sexual and Reproductive Rights.

3. Cortés Alfaro A, García Roché R, Duque Santana I, Ochoa Soto Aguilar Vald ZJ (2006) Methodology for the prevention of ITS-HIV/AIDS in adolescents and young people. National ITS/HIV/AIDS Prevention Center. Editorial Lazo Inside, Havana.

4. Torres Cueto MA (2011) Sexuality education and prevention of STIs and HIV/AIDS from gender, rights and sociocultural approaches. Basic Secondary Education, Pre-University, Professional and Adult Technique. Havana: Ministry of Education.

5. (2012) Sexuality Education Program with Gender Focus and Sexual Rights in the national education system. Ministerial Resolution No.139/2011. Ministry of Education, Havana.

6. Araujo Gonzalez R (2015) Vulnerability and health risk: Two cconcomitantc elevenpts? What's new in population. Center for Demographic Studies.

7. Díaz Machado A, Cruz Sánchez F, León Reyes S, Bess Constantén S, Podadera Valdés X (2016) Adolescence in cuba. Indicators of your health status, 2016. Rev ADOLECA.

8. World Health Organization (2016) Sexually transmitted infections.

9. WHO (2017) Adolescents: health risks and solutions.

10. (2011) Guidelines of the Economic and Social Policy of the Party and the Revolution. Havana: VI Party Congress.

11. Benavides Leal K, Alfaro Salas DP (2016) Teaching mediation strategies for education on sexually transmitted infections in adolescents. Rev. Current Nursing in Costa Rica 31.

12. Marquez F. Theoretical framework for health promotion and education.

13. Global Education Monitoring Report Team (2016) Education at the service of peoples and the planet: creating sustainable futures for all, summary of the monitoring report on education in the world 2016.

14. Cruz Sánchez F, Rodríguez Alonso B, Alonso Uría RU (2014) Childcare in adolescence. Havana: Ministry of Public Health p. 15-16.

15. Guerrero Borrego N, Pérez Enríquez M (2016) Integral education of sexuality in childhood, adolescence and youth. Conceptual approach. In Guerrero Borrego N. Reflections and looks on sexuality in childhood, adolescence and youth. Havana: CENESEX p. 21.

16. Cruz Sánchez F, Rodríguez Alonso B, Alonso Uría RU (2014) Adolescence and childcare. In Childcare in adolescence. Havana: Ministry of Public Health p. 21-23.

17. Santillano Cardenas I (2016) Comprehensive sexuality education in childhood, adolescence and youth. Conceptual approach. In Guerrero Borrego N. Reflections and looks on sexuality in childhood, adolescence and youth. Havana: CENESEX p 45.

18. Casales J (1982) Personality Attitudes. In: Kuzmin E. Selection of Social Psychology Readings. Havana, Cuba: University of Havana pp. 180-186.

19. (1974) Collective of Authors. Attitudes. Social Psychology materials series. Havana, Cuba: MINED.

20. UNICEF (2012) Progress for Children: A Report on Adolescents. Unite for childhood.

21. Morales Ojeda R (2015) Universal health coverage. Cuban experience. 
22. (2018) Ministry of Public Health. Statistical Health Yearbook, Cuba.

23. Castro Espín M, Rivero Pino R (2015) Government responsibility and comprehensive education of sexuality in Cuba. Havana: CENESEX.

24. Casanova Fabelo L, Estévez García KR (2016) Cuba in the post 2015 educational agenda. Rev Studio 20: 28-40.

25. (2016) Comprehensive Sexuality Education.

26. (2015) UN Audience Shocked by Sexual Health, Abortion Statistics. High-Level Working Group for CIPD. Rights, dignity and health for all Priorities for the post-2015 development agenda.

27. Yera EC, Roura SR, Jorlen AT (2017) Dealing with sexuality in adolescence. Humanidades Médicas 17(3): 577-592.

28. (2016) Why is Integral Sexuality Education important? 2016.

29. Gómez Suárez RT, Díaz Alvarez M, Sainz Rivero ER, Gómez Ibarra K, Machado Rodríguez R (2015) Educational actions on aspects of sexuality aimed at adolescents. Cuban Journal of Public Health 41(1): 57-66.

ISSN: 2574-1241

DOI: $10.26717 /$ BJSTR.2020.28.004632

Alba Cortes Alfaro. Biomed J Sci \& Tech Res

(C) This work is licensed under Creative

Submission Link: https://biomedres.us/submit-manuscript.php
30. (2010) International Technical Guidelines on Sexuality Education: An evidence-based approach to schools, teachers and health educators.

31. UNESCO (2008) Reflections on the evaluation of educational quality in Latin America and the Caribbean.

32. Pan American Health Organization (2003) Strengthening Regional Initiative Health Promoter Schools: Strategies and Lines of Action 20032012.

33. United Nations Organization (2015) Transforming our world: the 2030 Agenda for Sustainable Development.

34. Roca Zayas AA (2015) Integral Sexuality Education with a gender and law focus in the educational system. Ministry of Education. Havana.

35. Delgado Matos I, Delis Despaigne N, Infante Pineda A (2015) Intervention strategy for the development of knowledge on sexuality in adolescents of an urban basic secondary. MEDISAN 19(7): 50-61.

36. González Puerto Y, Morejón O, Morejón Barrueto Y, Sevilla G (2015) School: A link in health promotion on the HIV epidemic. Conrado Magazine 11(48): 42-47.

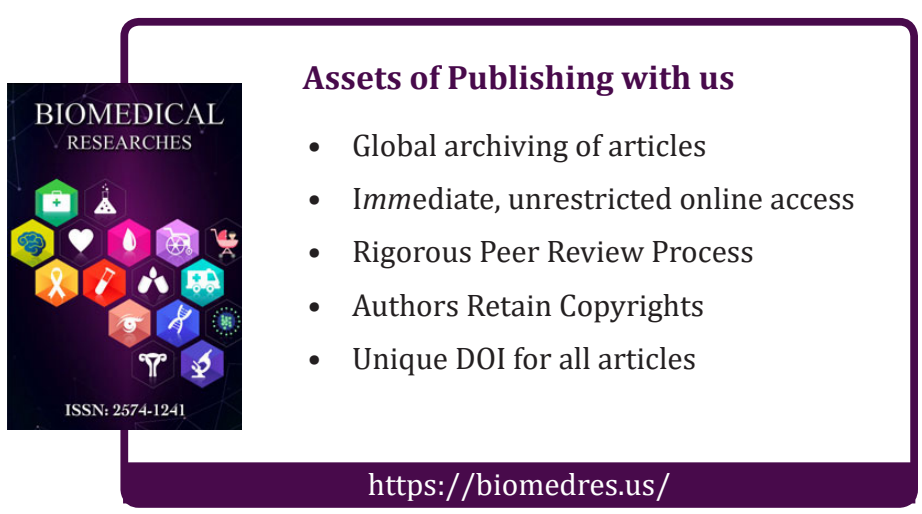

